\title{
ANALISIS PENGUKURAN KINERJA PEMERINTAH DAERAH DALAM ERA OTONOMI DAERAH DI KABUPATEN SORONG PROVINSI PAPUA BARAT
}

\author{
Yohanis S. Ulimpa ${ }^{1}$, Jullie J. Sondakh ${ }^{2}$, Treesje Runtu ${ }^{3}$ \\ 1,2,3 Jurusan Akuntansi, Fakultas Ekonomi dan Bisnis, Universitas Sam Ratulangi, Jl. Kampus Bahu, Manado, \\ 95115 Indonesia. \\ E-mail : malamoisarles@gmail.com
}

\begin{abstract}
In line with regional autonomy that is oriented towards empowerment (emporwerment) and community guidance in the implementation of clean authority and free of corruption, collusion and nepotism, the public sector is often regarded as a nest of wasteful efficiency and institutional fund leakage that always loses money. But the public sector still has wide opportunities to improve the performance of the benefits of resources economically, effectively and efficiently. Knowing the performance measurement of the Sorong Regency government. Knowing the role of indicators in the Sorong Regency government. The method used in this study is descriptive qualitative. The result is the performance measurement of the local government is carried out because of the provisions of the central government to make performance accountability reports for each government agency.

Keywords :Performance Measurement, Performance Indicator, LAKIP, Sorong District Government
\end{abstract}

\section{PENDAHULUAN}

Organisasi pemerintah adalah suatu institusi yang telah diberi kewenangan untuk mengurus kepentingan bangsa dan negara. Lembaga pemerintahan dibentuk pada umumnya untuk mengelola aktivitas pelayanan terhadap seluruh masyarakat, sebagai institusi nirlaba, pemerintah bertujuan bukan untuk mendapat keungtungan, tetapi tujuannya untuk menyediakan pelayanan dan meningkatkan kinerja untuk memberikan pelayanan kepada masyarakat dimasa yang akan datang. Pemerintahan merupakan suatu ilmu yang mempelajari tentang bagaimana menjalankan mengurus (eksekutif), mengatur (legislatif), memimpin dan mengkoordinasikan pemerintah pusat dengan daerah, maupun rakyat dengan pemerintahnya dalam berbagai suatu kejadian atau kondisi pemerintahan, secara baik dan benar (Syafiie 2011: 23). Adapun penelitian ini bertujuan yaitu untuk mengetahui analisis pengukuran kinerja pada pemerintah daerah Kabupaten Sorong di masa kemandirian daerah di Kabupaten Sorong Provinsi Papua Barat dan mengetahui peranan indikator kinerja dalam mewujudkan akuntabilitas pemerintah daerah Kabupaten Sorong Provinsi Papua Barat.

\section{TINJAUAN PUSTAKA}

Konsep Akuntasi. Akuntansi menurut Suwardjono (2014:5) merupakan seni untuk mencatat, menggolongkan, dan meringkas suatu transaksi dan peristiwa mengenai keuangan dengan metode yang berguna dalam bentuk uang, dan menginterpretasikan suatu hasil dari proses tersebut. Sedangkan Sujarweni (2015:1) menyatakan akuntansi merupakan suatu peristiwa jasa yang terdiri dari pencatatan, pengklasifikasian, dan pelaporan peristiwa atau suatu negosiasi perdagangan yang pada kemudian akan memberikan laporan mengenai finansial yang akan digunakan untuk parah bagian dalam mengambil ketetapan. Dari pengertian di atas, dapat disimpulkan akuntansi merupakan sebuah rangkaian kegiatan yang meliputi identifikasi dan pengukuran untuk pengambilan keputusan, pemrosesan data dan 
pelaporan informasi, dan pengkomunikasian informasi yang digunakan oleh pengguna laporan.

Akuntansi Sektor Publik. Surjaweni (2015:1) menyatakan akuntasi sektor publik dapat merupakan suatu kegiatan jasa yang terdiri dari pencatatan, pengklasifikasian dan pelaporan suatu peristiwa negosiasi perdagangan yang akan mengeluarkan laporan mengenai keuangan yang diperlukankan untuk parah golongan dalam mengambil suatu langkah untuk digunakan dalam mengelola dana publik di lembaga Negara dan di organisasiorganisasi dibawahnya.

Laporan Keuangan Daerah. Laporan keuangan pemerintah daerah disajikan sebagai informasi yang mempunyai manfaat untuk para pengguna dalam menilai suatu akuntabilitas dan mengambil suatu keputusan ekonomi, social dan politik dalam menyediakan suatu informaasi. (Tanjung, 2012).

Tujuan dan Manfaat Pengukuran Kinerja. Kinerja yang dillaksanakan pada kegiatan yang bisa diukur dan akan memajukan pencapaian kinerja tersebut. Pengukuran kinerja yang dilaksanakan secara berkelanjutan yang dapat memberikan umpan balik untuk usaha mempebaiki secara berkelanjutan dan pencapaian tujuan di waktu yang akan dating (Mardiasmo, 2002).

Aspek Yang Diukur Pada Pengukuran Kinerja. Pengukuran prestasi biasanya aspek yang dilaksanakan pada pengukuran prestasi yaitu : Aspek Finansial, kepuasaan pelanggan, operasi dan paasar internal, pepuasan pegawai, kebahagian komunitas Shareholder/ Stakeholder dan waktu (Indra Bastian,2001).

Pengukuran Kinerja Pemerntah Daerah di Era Otonomi. Dalam rangka meningkatkan pelaksanaan pemerintah yang efesien, efektif dan akuntabel di era otonomi daerah, pemerintah telah mengeluarkan Inpres 1999 tentang setiap institusi pemerintah sebagai bagian pelaksana pemerintah negara sejak awal pimpinan Esalon II ke atas perlu menpertanggun jawabkan peran penting dan manfaatnya serta kekuasaan pengendalian sumber daya dan kebijakan yang sudah mengakui pada beralaskan perancangan strategi yang disusun pada ringkasan sebelumnya (LAN dan BPKP, 2000). Implekasi inpres nomor 7 tahun 1999 bagi perintah daerah tiap-tiap bidang kerja institusi pemerintah daerah diharuskan menerbitkan indikator prestasi sebagai bagian dari informasi akuntabilitas prestasi Pembuatan Laporan Akuntabilitas Kinerja Pemerintah (LAKIP) bagi instansi pemerintah bersifat mandatori. Karena sifatnya mandatory, maka semua instansi pemerintah harus melakukannya dan dalam pelaksanaannya mengikuti pedoman yang dikeluarkan, dalam hal ini pedoman menyusun LAKIP yang telah dikeluarkan oleh lembaga adminitrasi negara.

Kerangka Pengukuran Kinerja Model LAKIP. Kerangka pengukuran kinerja model LAKIP terdiri atas dua bagian utama, yaitu penetapan indikator kinerja dan penetapan pencapaian kinerja.

Tujuan Otonomi Daerah. Mengubah kesadaran masyarakat. Pembangunan satu daerah dapat disamakan oleh pemerintah daerah dengan daya dan ciri khas wilayah. Penerapan kemandirian wilayah adalah inti pusat yang utama pada bentuk masing-masing.

\section{METODE PENELITIAN}

Jenis Penelitian. Bentuk penelitan merupakan penelitian secara mendalam untuk memberi gambaran dan perkembangan dari suatu objek dalam penelitian ini strategi yang dipergunakan melalui metode kualitatif yakni sumber dari deskriptif, Miles dan Huberman dalam (Silalahi, 2012).

Tempat dan Waktu Penelitian. Lokasi penelitian diKabupaten Sorong Provinsi Papua Barat. Tempatnya pada Kantor Bupati Kabupaten Sorong, yang beralamat di Jl. Sorong Klamono Kilo Meter 24 Kabupaten Sorong Papua Barat dan letaknya cukup strategis karena berada di Pinggiran Kota sehingga mudah di jangkau. Kabupaten Sorong merupakan sebuah 
Kabupaten di Provinsi Papua Barat. Waktu penelitan yang digunkan dalam penelitian kurang lebih 2 bulan mulai dari Juli hingga Agustus 2017.

Prosedur Penelitian. Langkah-langkah yang digunakan pada pelaksanaan penelitian ini adalah sebgai berikut:

1. Menujukan permohonan penelitian

2. Disposisi pimpinan

3. Pengambilan data

4. Analisis data

5. Menarik kesimpulan dan memberikan saran.

Jenis Data. Bentuk data yang pakai yaitu pada (Kuncoro 2009) merupakan : Kualitatif yakni data yang disajikan secara deskriptifatau berbentuk uraian. Data kualitatif pada penelitian ini bermuat tentang posisi lembaga tempat penelitian.

Metode Analisis. Metode yang digunakan pada penelitian yaitu desain kajian deskriptif, yakni desain pengkajian kasus sifatnya sia-sia menggambarkan, menilai suatu fakta dan kejadian.

\section{HASIL ANALISIS DAN PEMBAHASAN}

\subsection{Struktur Organisasi}

Struktur organisasi pemerintah daerah Kabupaten Sorong terdiri dari :

1. Bupati

2. Wakil bupati

3. DPRD

4. Staf ahli bupati

5. Sekretariat daerah

6. Asisten sosial pemerintahan

7. Asisten pengembangan ekonomi

8. Asisten adminitrasi umum

9. Instansi vertikal BUMN dan BUMD

10. DistrikDistrik terdiri dari 32

11. Kelurahan Kelurahan terdiri dari 26 kelurahan

12. Badan daerahBadan daerah terdiri dari 7 badan daerah

13. Inspektorat

14. Sekretariat DPRD

Karakteristik Informan. Pada penelitian ini para informan yang berjenis kelamin laki-laki lebih banyak dibandingkan dengan para informan perempuan. Untuk lebih jelas dapat pada Tabel 1.

Tabel 1. Identifikasi Informan Berdasarkan Jenis Kelamin

\begin{tabular}{ccc}
\hline Jenis Kelamin & Jumlah Informan (Orang) & Presentase \\
\hline Laki-laki & 8 & 53,33 \\
Perempuan & 7 & 46,66 \\
Jumlah & 15 & $100 \%$ \\
\hline
\end{tabular}

Sumber Data: Data Diolah 2017

Usia Informan. Berdasarakan data yang diperoleh, usia informan berkisar antara 31-57 tahun, komposisi usia informan dalam penelitian disajikan dalam Tabel 2. Tabel menunjukan bahwa jumlah informan pada usia 31-40 tahun menunjukan presentase yaitu sebanyak 5 $(33,33 \%)$. Dan pada usia 40-57 tahun menunjukan presentase yaitu sebanyak $10(66,66 \%)$. 


\begin{tabular}{llcc}
\hline \multicolumn{4}{c}{ Tabel 2. Indentifikasi Informan Berdasarkan Tingkat Usia } \\
\hline No. & \multicolumn{1}{c}{ Usia } & Jumlah Informan (Orang) & Presentase \\
\hline 1 & $3-40$ & 5 & 33,33 \\
2 & $40-57$ & 10 & 66,66 \\
& Jumlah & 15 & $100 \%$ \\
\hline
\end{tabular}

Sumber Data: Data Diolah 2017

Tingkat Pendidikan Informan. Peran pendidikan formal sangatlah penting dalam usaha peningkatan kualitas seseorang karena berguna dalam membangun serta peningkatan intektual dan wawasan seseorang. Berdasarkan hasil penelitian ini tinggkat pendidikan informan sangat bervariasi mulai dari Strata 1(S1 sampai Strata 2 (S2). Komposisi tingkat pendidikan informan dapat dilihat pada Tabel 3.

Tabel 3. Identifikasi Informan Berdasarkan Tingkat Pendidikan

\begin{tabular}{llcc}
\hline No. & Tingkat Pendidikan & Jumlah Informan (Orang) & Presentase \\
1 & Strata 1 (S1) & 4 & 26.6 \\
2 & Strata 2 (S2) & 11 & 73.3 \\
& Jumlah & 15 & $100 \%$ \\
\hline
\end{tabular}

Sumber Data: Data Diolah 2017

Mengacu pada Peraturan Bupati Sorong Nomor 26 Tahun 2015 tentang Indikator Kinerja Utama di Lingkungan Pemerintah Daerah Kabupaten Sorong Tahun 2016, maka sasaran dalam rangka mencapai visi, misi dan tujuan Dinas Pekerjaan Umum adalah sebagai berikut :

1. Misi I terdapat 2 tujuan, 11 sasaran dan 13 indikator kinerja.

2. Misi II terdapat 1 tujuan, 1 sasaran dan 4 indikator kinerja.

3. Misi III terdapat 1 tujuan, 1 sasaran dan 2 indikator kinerja

Tabel 4. Pencapaian Indikator Sasaran

\begin{tabular}{cccccc}
\hline No. & Misi & $\begin{array}{c}\text { Jumlah } \\
\text { Tujuan }\end{array}$ & $\begin{array}{c}\text { Jumlah } \\
\text { Sasaran }\end{array}$ & $\begin{array}{c}\text { Jumlah Indikator } \\
\text { Kinerja Sasaran }\end{array}$ & $\begin{array}{c}\text { Pencapaian } \\
\text { Indikator Sasaran }\end{array}$ \\
\hline 1 & Misi I & 4 & 11 & 13 & $\begin{array}{c}\text { BS=-, B=13, C=-, K=- } \\
\text { BS =-, B=4, C=-, K=- }\end{array}$ \\
& $\begin{array}{c}\text { Misi } \\
\text { II }\end{array}$ & 1 & 1 & 4 & \\
3 & $\begin{array}{c}\text { Misi } \\
\text { III }\end{array}$ & 1 & 1 & 2 & BS=-, B=2, C=-, K=- \\
& & 13 & & 19 \\
\hline
\end{tabular}

Sumber Data: Badan Pengelolahan Keuangan Dan Aset Daerah Kabupaten Sorong

Hasil analisis pencapaian indikator sasaran terhadap sasaran yang mencakup 15 indikator sasaran diketahui bahwa 15 indikator sasaran atau $100 \%$ Baik. Rata-rata realisasi capaian kinerja mencapai 100\%. Jadi capaian kinerja Pemerintah Kabupaten Sorong pada tahun 2016 dengan kategori Baik. Hal ini dapat dilhat pada Tabel 5. 
Tabel 5. Persentase Kategori Pencapaian Indikator Sasaran

Misi I : 11 Indikator Sasaran

\begin{tabular}{cccc}
\hline No. & Kategori & Jumlah Indikator Sasaran & Presentase \\
\hline 1 & Baik Sekali & & 100 \\
2 & Baik & & \\
3 & Cukup & & \\
4 & Kurang & & \\
5 & Nilai Belum Keluar &
\end{tabular}

Misi II : 4 Indikator Sasaran

$\begin{array}{lc}1 & \text { Baik Sekali } \\ 2 & \text { Baik } \\ 3 & \text { Cukup } \\ 4 & \text { Kurang } \\ & \text { Jumlah }\end{array}$

Misi III : 2 Indikator Sasaran

$\begin{array}{lccc}1 & \text { Baik Sekali } & 2 & 100 \\ 2 & \text { Baik } & - & \\ 3 & \text { Cukup } & - & 100 \\ 4 & \text { Kurang } & & \\ & \text { Jumlah } & \end{array}$

Sumber Data: Badan Pengelolahan Keuangan Dan Aset Daerah Kabupaten Sorong

\subsection{Pembahasan}

\begin{tabular}{|c|c|c|c|c|c|c|c|c|c|c|c|}
\hline No. & $\begin{array}{c}\text { Indikator } \\
\text { Kinerja }\end{array}$ & Satuan & & Target & & & ealisa & & & paian & \\
\hline & Utama & & & & & & & & & & \\
\hline 2 & Ketersedian rumah & Unit & 20 & 20 & 20 & 20 & 20 & 20 & 20 & 20 & 20 \\
\hline & layak huni & & 14 & 15 & 16 & 14 & 15 & 16 & 14 & 15 & 16 \\
\hline & & & 62 & 166 & 75 & 62 & 166 & 75 & 100 & 100 & 100 \\
\hline Rata & -rata kapaian kinerja & & & & & & & & 100 & 100 & 100 \\
\hline Suml & Data: Badan Peng & han 1 & & $\overline{a n}$ & $t D$ & $\overrightarrow{r a l}$ & $a b l$ & $t e$ & Soron & & \\
\hline ne & $\begin{array}{l}\text { Berdasarkan Tabel } \\
\text { ayaan untuk perbaik } \\
\text { i pencapaian } 1 \text { indil } \\
\text { a sasaran pada tahun } \\
\text { n kinerja tahun } 2015\end{array}$ & $\begin{array}{l}\text { diatas d } \\
\text { dan pen } \\
\text { r, } 1 \text { inc } \\
6 \text { sebes } \\
\text { esar } 100\end{array}$ & 00 & $\begin{array}{l}\text { bahy } \\
\text { in ru } \\
\text { ssara }\end{array}$ & $\mathrm{sa}$ & an & erla & an & $y a$ & tem & $\begin{array}{l}\text { ola } \\
\text { kur } \\
\text { aian } \\
\text { rata }\end{array}$ \\
\hline
\end{tabular}

\section{Analisis Akuntabilitas Keuangan}

1. Penerimaan

Penerimaan setelah pergantian sebesar $\mathrm{Rp} 230.000 .000$ setelah perubahan sebesar Rp 230.000 .00

2. Belanja

Belanja sebelum perubahan sebesar Rp 301.945.009.000 setelah perubahan sebesar Rp 369.062.079.000 (Bertambah Rp 67.117.070.000) 


\section{KESIMPULAN DAN SARAN}

\subsection{Kesimpulan}

Melalui hasil penelitian di lapangan, yan dapat dimpulan adalah

a. Anaslisis pengukuran prestasi pemerintah daearah dibuat berdasarkan petujuk dari pemerintah pusat untuk membuat informasi akuntabilitas prestasi bagi setiap institusi pemerintah daerah.

b. Model pengukuran kinerja pemerintah daerah di era otonomi daerah telah menggunakan indikator input, output, outcome, benefit, dan inpact. Model ini sesuai dengan ketentuan dalam LAKIP. Tetapi terdapat kelemahan sistem pengukuran kinerja pemerintah daerah pada saat ini yaitu pengukuran kinerja belum berfokus pada outcome akan tetapi masih berorientasi pada output. Hal ini dikarenakan pemerintah daerah mampu menentukan indikator outcome, benefit, dan inpact secara tepat.

\subsection{Saran}

Melui penelitian ini yang menjadi saran bagi peneliti adalah:

a. Pemerintah daerah perlu membuat penambahan standar indikator cakupan, layanan kepuasan pelanggan, pencapaian tujuan dalam desain pengukuran kinerjanya dimana tidak hanya sebatas indikator input, output, outcome dan inpact

b. Indikator kinerja bersama laporan kinerja perlu dipublikasikan kepada masyarakat agar publik bisa mengakses informasi kinerja pemerintah

\section{DAFTAR PUSTAKA}

Bastian, Indra, 2001. Akuntansi sektor Publik di Indonesia, Pusat Pengembagan

Akuntansi Fakultas Ekonomi, Universitas Gajah Madah

Badan Kesekretariatan Daerah Kabupaten Sorong Provinsi Papua Barat.

Halim, Abdula dan Muhammat S. Kusufi.2012. Akuntansi Sektor PublikAkuntansi

Keuangan Daerah Edisi Empat Penerbit: Erlangga, Jakarta

Hery. 2012. Cara mudah memahami Akuntansi (Inti Sari Konsep Dasar Akuntansi). Prenada Media Group. Jakarta.

Instruksi Presiden No. 7 Tahun 1999 tentang Akuntabilitas Kinerja Instansi Pemerintah.

Suwardjono, 2014. Teori Akuntansi Perekayasa Pelaporan Keuangan Edisi Ketiga.

Surjaweni,2015. Sistem Akuntansi Sektor Publik

Tanjung, Abdul Hafis. 2012. Akuntansi Pemerintah Daerah Berbasis Akrual.

Penerbit: Alfabeta, Bandung.

Lembaga Adminitrasi Negara dan BPKP (2000) Akutabilitas dan Good Governance,

Model Sosalisasi Sistem Akuntabilitas Kinerja Instansi Pemerintah

Miles dan Huberman dalam (Silalahi, 2012:284) 